\title{
Structure for Knowledge Creation in Nepalese Hospitality Industry
}

\author{
Pushpa Maharjan'
}

\begin{abstract}
This paper examines the different factors promoting structure for knowledge creation in the business enterprises of sectors such as hotel, travel and trekking agencies. The survey was conducted in the month of May, 2015 in Kathmandu valley. The totals of 382 responses were taken for analysis. The total response rate was 83 per cent. Self-administered questionnaires were used to collect the perceptive opinions from the respondents. The study concludes that the majority of employees of the hospitality industry do not need to refer to someone else in decision making processes and have to perform many activities that are not covered by some formal procedures.
\end{abstract}

Key words: Centralization, Formalization, Knowledge Creation

\section{BACKGROUND AND OBJECTIVE}

Nepalese hospitality industry is very competitive. Knowledge is a resource to gain competitive advantage in this sector. It requires obtaining comprehensive information on how knowledge is managed and utilized in hospitality industry. It is also necessary to examine the organisational culture, structure, information technology, processes and creativity that are essential in managing the performance in hospitality industry in order to make it more efficient.

Berraies, Chaher, and Yahia (2014) found that the best path for Tunisian ICT companies to foster knowledge creation was through decentralized and low formalized structure. According to Wang and Ahmed (2004) evaluated that organic structure promotes a metaphor in which organisations are seen as complex and social entities featured by a collection of competing and interacting forces between individuals and social forces. The organic structure has the following dimensional characteristics:

- Flat and team-based. There is a shift from vertical decision making to horizontal collaboration. Organisations composition typically consists of top management, strategic groups and project teams.

1. Dr. Maharjan is Lecturer at Public Youth Campus, Tribhuvan University. She can be reached at s3pushpam@gmail.com 
- Divisionalised: Departmental barriers erode to facilitate cross-functional teams and integration of specialised sources of knowledge (Cross, 2000).

- Decentralisation of power and control: Managers empower employees to proactively participate in organisational management and promote a culture of openness and trust.

- A higher level of informality: There is freedom from rules; there is more informal, faceto-face communication and two loops of communications, downwards and upwards; management expands to include managing people, technology, knowledge, and processes.

Organisation structure can encourage or inhibit knowledge management implementation (Hopper, 1990; Ein-Dor \& Segev, 1982; Caruana et al., 1998). Ichijo et al. (1998) emphasized that firms should maintain consistency between their structures and how they plan to practically use their knowledge. Organisation structure should be designed in such a way that it can create the foundation for knowledge creation and act in line with knowledge management system. It is important that organisation structure is designed flexible enough to encourage creating and sharing knowledge across organisation boundaries. Many researchers have recommended flexible organisation structure for effective knowledge management (Menon \& Varadarajan, 1992). Organisation structure is one of the main Knowledge Management Enablers that consist of two variables: centralisation and formalisation. Both are recognized as key variables underlying the organisation structure and have strong effect on knowledge management (Johannenssen et al., 1999; Kanevsky \& Housel, 1998).

Centralisation implies the location of decision authority and control within an organisation. The centralisation of decision making authority inevitably reduces creative solutions. Scattering the decision making power facilitates spontaneity, experiment, and expressional freedom. These are the critical forces of knowledge creation. Thus, many researchers believe that a centralised organisation structure makes knowledge creation harder (Nevis et al., 1995; Nonaka \& Takeuchi, 1995; O’Dell \& Grayson, 1999). Zaltman (1986) stated that in a less centralised organisation structure, more knowledge is created. In addition, centralised structure prevents free interdepartmental communication and sharing of ideas due to the high amount of time spent on communication channels (Raven \& Prasser, 1996). It also causes falsification and standing of ideas (Nonaka \& Takeuchi, 1995).

Formalisation refers to the degree to which decisions and working relationships are managed by formal rules, procedures, and standard policies (Chase, 1998; Hopper, 1990; Zucker et al., 1996). Knowledge creation requires flexibility rather than work rules (Bennett \& Gabriel, 1999). It seems that when strict formal rules dominate an organisation, the range of new ideas shrinks. Thus, flexibility can provide better ways of doing things (Nelson \& Cooprider, 1996). When flexibility increases in an organisation structure, knowledge creation tends to increase as well. Knowledge creation also requires variation. In order to be more adaptable when confronting unexpected problems, an organisation 
may accommodate variation in both of its processes and structure (Kreitner \& Kinicki, 1992). The more formalisation is wiped from the organisation processes, the more openness and variation can evolve to support new ideas and behaviors (Damanpour, 1991). Through wide communications and interactions, knowledge creation is likely to be encouraged (Sawhney \& Prandelli, 2000). Formalisation restrains the communication and interaction that are necessary to create knowledge. Lack of formal structure enables employees to interact and communicate each other to access knowledge and its fluent flow (Jarvenpaa \& Staples, 2000).

The objective of the study is to examine the different factors promoting structure for knowledge creation in the business enterprises of sectors such as hotel, travel and trekking agencies. Remaining part of the paper has been divided in three sections. Second section presents the research methodology, third section reveals presentation and analysis of data and the final section presents the conclusion of the study.

\section{RESEARCH METHODOLOGY}

This study largely followed the methodology used by Choi (2002). Basically, it is a descriptive study having the features of survey research. For collecting primary data, a survey technique was been adopted. The study considered hospitality industry of Nepal as its population. However, for convenience, samples were taken only from hotels and travel/trekking agencies from within Kathmandu valley. Hospitality industry was further categorized into two groups, namely, hotels and travel/trekking agencies. 38 hotels and 59 travel/ trekking agencies were selected as sample on the basis of judgmental sampling. Employees of executive, officer and non-officer levels in Nepalese hospitality industry are the respondents of the study. The survey was conducted in the month of May 2015. Of the 458 questionnaires distributed to the respondent-employees, 382 responses were usable making the response rate of 83 per cent.

The descriptive statistical tools were used for the data analysis and presentation. To evaluate and test the various statements in the response, mean values of each variable, standard deviation and ranking were used as per the need of the study.

\section{PRESENTATION AND ANALYSIS OF DATA}

Table 1 presents the demographic information of the respondents. As the table shows, the majority of the respondents were male (63.6\%) and were in the age group of $20-35$ years $(66.2 \%)$. In terms of marital status, they are almost equally divided. Majority of the respondents are graduates $(46.9 \%)$, work in middle and operational level $(88.7 \%)$ and have less than five years of experience in the current position $(56.3 \%)$. 
40 I PYC Nepal Journal of Management, August 2018, Vol. XI, No. 1

Table 1: Demographic Data for the Respondents of the Main Survey

Table X

\begin{tabular}{|c|c|c|}
\hline Demographic Object & Items & Percent \% \\
\hline \multirow{3}{*}{ Sex } & Male & 63.6 \\
\hline & $\begin{array}{l}\text { Female } \\
<20\end{array}$ & $\begin{array}{c}36.4 \\
4.5\end{array}$ \\
\hline & $20-35$ & 66.2 \\
\hline \multirow[t]{4}{*}{ Manager's age } & $36-50$ & 24.1 \\
\hline & $51-65$ & 4.7 \\
\hline & $>65$ & 0.5 \\
\hline & Higher secondary & 24.1 \\
\hline \multirow{5}{*}{ Manager's highest level of education } & Bachelor's degree & 46.9 \\
\hline & Master's degree & 28.5 \\
\hline & Ph. D. & 0.5 \\
\hline & $<5$ & 56.3 \\
\hline & $6-10$ & 13.6 \\
\hline \multirow[t]{4}{*}{ Manager's work experience } & $11-15$ & 12.0 \\
\hline & $16-20$ & 7.4 \\
\hline & $>20$ & 10.7 \\
\hline & Married & 50.3 \\
\hline \multirow[t]{4}{*}{ Marital status } & Single & 49.4 \\
\hline & Others & 0.3 \\
\hline & Human resources & 12.6 \\
\hline & Finance/Accounting & 16.2 \\
\hline \multirow{5}{*}{ Manager's current department } & Sales & 24.8 \\
\hline & IT & 5.0 \\
\hline & Public relations & 27.0 \\
\hline & Marketing & 14.4 \\
\hline & Top management level & 11.3 \\
\hline \multirow[t]{2}{*}{ Manager's current position } & Middle management & 47.9 \\
\hline & levelOperating level & 40.8 \\
\hline
\end{tabular}

Source: Questionnaire survey, 2015

The questionnaire contained a list of different statements of observations regarding different factors promoting structure for knowledge creation. The respondents were requested to express their agreement/ disagreement on the given statements by using a seven-point Likert Scale.

The mean values of observation statements varied from 3.03 to 3.95 . The majority of the respondents identified that centralisation for knowledge creation mainly affected by "employees in organisation do not need to refer to someone else". Similarly, they thought "employees in organisation do not need to ask supervisor before action" as the second important factor influencing knowledge creation. 


\section{Table 2: Promoting Factors for Centralisation}

This table reports mean weightage, std. deviation and rank of the responses on the given statements. The mean values, std. deviation and rank of centralisation are presented as well.

\begin{tabular}{clccc}
\hline S. No. & \multicolumn{1}{c}{ Statements } & Mean & $\begin{array}{c}\text { Std. } \\
\text { Deviation }\end{array}$ & Rank \\
\hline a. & Centralisation (locus of decision authority) & & & \\
1. & Employees in this organisation do not need to refer to someone else. & 3.95 & 1.622 & 1 \\
2. Employees in this organisation do not need to ask their supervisor & 3.27 & 1.734 & 2 \\
3. & Eefore action. & 3.03 & 1.793 & 3 \\
\hline
\end{tabular}

Source: Questionnaire survey, 2015

Therefore, it can be concluded that the employees of the hospitality industry in Nepal acquire more decision making authority so they do not need to refer to someone else or seniors for decision making. The findings are similar to the study of Migdadi (2005), who discovered that "company members can make decisions without approval" and "company members do not need to ask supervisors before action" are first and second influencing factors for knowledge creation.

\section{Table 3: Promoting Factors for Formalisation}

This table reports mean weightage, std. deviation and rank of the responses on the given statements. The mean values, std. deviation and rank of formalisation (formal rules, procedures, and standard policies) are presented as well.

\begin{tabular}{clccc}
\hline S. No. & \multicolumn{1}{c}{ Statements } & Mean & $\begin{array}{c}\text { Std. } \\
\text { Deviation }\end{array}$ & Rank \\
\hline b. & Formalisation (formal rules, procedures and polocies) & & & \\
$1 . \quad \begin{array}{l}\text { In this organisation, there are many activities that are not covered by } \\
\text { some formal procedures. }\end{array}$ & 3.97 & 1.645 & 1 \\
2. $\quad \begin{array}{l}\text { Employees in this organisation can ignore the rules and reach } \\
\text { informal agreements to handle some situations. }\end{array}$ & 3.42 & 1.780 & 2 \\
3. $\quad \quad$ Employees in this organisation make their own rules on the job. & 2.94 & 1.833 & 3 \\
\hline
\end{tabular}

Source: Questionnaire survey, 2015

The mean values of observation statements varied from 2.94 to 3.97 . The majority of the respondents identified that formalisation for knowledge creation mainly affected by "there are many activities that are not covered by some formal procedures". Similarly, they thought "employees can ignore the rules and reach informal agreements to handle some situations" as the second important factor, influencing knowledge creation. It can be concluded that employees of the hospitality industry have recognized that many activities in their organisations are not covered by some formal procedures indicating their level of formalisation.

\section{CONCLUSION}

Nepalese hospitality industry employees do not need to refer to someone else and they do not need to ask supervisor before action have a larger impact on the knowledge creation while they can make decisions without approval influences less. Many activities that are not covered by some formal procedures and employees can ignore the rules and reach informal agreements to handle some situations have a larger impact on the knowledge creation while make their own rules on the job influences less. 


\section{REFERENCES}

Bennett, R., \& Gabriel, H. (1999). Organizational factors and knowledge management within large marketing departments: An empirical study. Journal of Knowledge Management, 3(3), 212225.

Berraies, S., Chaher, M., \& Yahia, K. B. (2014). Knowledge management enablers, knowledge creation process and innovation performance: An empirical study in Tunisian information and communication technologies sector. Business Management and Strategy, 5(1), 1-26.

Caruana, A., Morris, M. H., \& Vella, A. J. (1998). The effect of centralization and formalization on entrepreneurship in export firms. Journal of Small Business Management, 36(1), 16-29.

Chase, R. L. (1998). The people factor. People Management, 22, 38.

Choi, B. (2002). Knowledge management enablers, processes, and organization performance: An integration and empirical examination. (Ph. D. Thesis, Division of Management Engineering, Korea Advanced Institute of Science of Technology, 2002).

Cross, R., \& Baird, L. (2000). Technology is not enough: Improving performance by building organizational memory. Sloan Management, 69-78.

Damanpour, F. (1991). Organizational innovation: A meta-analysis of effects of determinants and moderators. Academy of Management Journal, 3, 220-227.

Ein-Dor, P., \& Segev, E. (1982). Organizational context and MIS structure: Some empirical evidence. MIS Quarterly, 6(3), 55-68.

Hopper, M. D. (1990). Rattling SABRE-new ways to compete on information. Harvard Business Review, 118-125.

Ichijo, K., Krogh, G., \& Nonaka, I. (1998). Knowledge enablers. In G. Krogh, J. Roos, \& D. Kleine (Eds.), Knowing in companies (173-203). Thousand Oaks, CA: Sage.

Jarvenpaa, S. L., \& Staples, D. S. (2000). The use of collaborative electronic media for information sharing: An exploratory study of determinants. Strategic Information Systems, 9, 129-154.

Johannenssen, J. A., Olsen, B., \& Olaisen, J. (1999). Aspects of innovation theory based on knowledge management. International Journal of Information Management, 19, 121-139.

Kanevsky, V., \& Housel, T. (1998). The learning-knowledge-value cycle. In G. Krogh, J. Roos, \& D. Kleine (Eds.), Knowing in Thousand Oaks Firms (269-284). CA: Sage Publications.

Kreitner, R., \& Kinicki, A. (1992). Organizational behaviour. Homewood, II, Richard D. Irwin.

Menon, A., \& Varadarajan, R. (1992). A model of marketing knowledge use within firms. Journal of Marketing, 56, 53-71.

Migdadi, M. M. (2005). An integrative view and empirical examination of the relationships among knowledge management enablers, processes and organizational performance in Australian Enterprises, (Ph. D. Dissertation, School of Economics and Information Systems, University of Wollongong, 2005).

Nelson, K. M., \& Cooprider, J. G. (1996). The contribution of shared knowledge to IS group performance. MIS Quarterly, 20(4), 409-429.

Nevis, E., Anthony, D., \& Gould, J. (1995). Understanding organizations as learning systems. Sloan Management Review, 73-85.

Nonaka, I., \& Takeuchi, H. (1995). The knowledge-creating company: How Japanese companies create the dynamics of innovation. Oxford: Oxford University Press.

O'Dell, C., \& Grayson, J. (1999). Knowledge transfer: Discover your value proposition. Strategy and Leadership, 27(2), 10-15.

Raven, A., \& Prasser, S. G. (1996). Information technology support for the creation and transfer of tacit knowledge in organizations. Association for Information Systems 1996 Americas Conference. Retrieved from http:// hsb.baylor.edu/ ramsower/ais.ac.96/papers/RAVEN.htm

Sawhney, M., \& Prandelli, E. (2000). Communities of creation: Managing distributed innovation in turbulent markets. California Management Review, 42(4), 24-54.

Wang, C. L. Z., \& Ahmed, P. K. (2004). The development and validation of the organizational innovativeness construct using confirmatory factor analysis. European Journal of Innovation Management, 7(4), 303-313. 
Zaltman, G. (1986). Knowledge utilization as planned social change. In G. Beal, W. Dissanayake, \& S. Konoshima (Eds.), Knowledge Generation, Exchange and Utilization (433-462). Boulder, CO: The Westview Press.

Zucker, L. G., Darby, M. R., Brewer, M. B., \& Peng, Y. (1996). Collaboration structures and information dilemmas in biotechnology: Organization boundaries as trust production. In R. M. Kramer, \& T. R. Tyler (Eds.), Trust in Organizations: Frontiers of Theory and Research (90-113). Thousand Oaks, CA: Sage.

\section{Annex}

\section{Survey Questionnaire on}

Structure for Knowledge Creation in Nepalese Hospitality Industry

\section{Part I: Personal background}

1. Sex: (1) $\square$ Male (2) $\square$ Female

2. Age: years old

3. Highest educational level:

(a) $\square$ Plus two

(b) $\square$ Bachelor's degree

(c) $\square$ Master's degree

(d) $\square$ Ph. D.

4. Work Experience: (a) $\square$ 0-5 years (b) $\square 6$-10 years (c) $\square$ 11-15 years

(d) $\square$ 16-20 years (e) $\square 21$ years and above

5. Marital status: (a) $\square$ Married (b) $\square$ Single (c) $\square$ Others

6. Current department: (a) $\square$ Human Resources (b) $\square$ Finance/Accounting (c) $\square$ Sales

(d) $\square$ IT (e) $\square$ Public Relations (f) $\square$ Marketing

7. Current position: (a) $\square$ Top Management Level (b) $\square$ Middle Management Level

(c) $\square$ Operational Level 


\section{Part II: Survey questions}

Please tick $(\sqrt{ })$ on your choice by using the following scale in your ratings to indicate how much you agree/disagree with the following statements.

1

Strongly

Disagree
2

Disagree

3

Slightly

Disagree
4

Neutral $\begin{array}{lll}5 & 6 & 7\end{array}$

Slightly Agree Strongly

\begin{tabular}{|c|c|c|c|c|c|c|c|c|}
\hline S.No. & Factors & SD 1 & D 2 & SD 3 & N 4 & SA 5 & A 6 & SA 7 \\
\hline a. & Centralization & 1 & 2 & 3 & 4 & 5 & 6 & 7 \\
\hline 1. & $\begin{array}{l}\text { Employees in this organisation do not need } \\
\text { to refer to someone else. }\end{array}$ & & & & & & & \\
\hline 2. & $\begin{array}{l}\text { Employees in this organisation do not need } \\
\text { to ask their supervisor before action. }\end{array}$ & & & & & & & \\
\hline 3. & $\begin{array}{l}\text { Employees in this organisation can make } \\
\text { decisions without approval. }\end{array}$ & & & & & & & \\
\hline b. & Formalization & 1 & 2 & 3 & 4 & 5 & 6 & 7 \\
\hline 1. & $\begin{array}{l}\text { In this organisation, there are many } \\
\text { activities that are not covered by some } \\
\text { formal procedures. }\end{array}$ & & & & & & & \\
\hline 2. & $\begin{array}{l}\text { Employees in this organisation can ignore } \\
\text { the rules and reach informal agreements to } \\
\text { handle some situations. }\end{array}$ & & & & & & & \\
\hline 3. & $\begin{array}{l}\text { Employees in this organisation make their } \\
\text { own rules on the job. }\end{array}$ & & & & & & & \\
\hline
\end{tabular}

